\title{
Biochemistry of Nitric Oxide
}

\author{
Safia Habib $\cdot$ Asif Ali
}

Received: 1 January 2011/Accepted: 1 January 2011/Published online: 3 February 2011

(C) Association of Clinical Biochemists of India 2011

\begin{abstract}
Nitric oxide (NO) a free radical having both cytoprotective as well as tumor promoting agent is formed from L-arginine by converting it to L-citrulline via nitric oxide synthase enzymes. The reaction product of nitric oxide with superoxide generates potent oxidizing agent, peroxynitrite which is the main mediator of tissue and cellular injury. Peroxynitrite is reactive towards many biomolecules which includes amino acids, nucleic acid bases; metal containing compounds, etc. NO metabolites may play a key role in mediating many of the genotoxic/ carcinogenic effects as DNA damage, protein or lipid modification, etc. The basic reactions of nitric oxide can be divided as direct effect of the radical where it alone plays a role in either damaging or protecting the cell milieu and an indirect effect in which the byproducts of nitric oxide formed by convergence of two independent radical generating pathways play the role in biological reactions which mainly involve oxidative and nitrosative stress. Nitric oxide is also capable of directly interacting with mitochondria through inhibition of respiration or by permeability transition. Reaction of nitric oxide with metal ions include its direct interaction with the metals or with oxo complexes thereby reducing them to lower valent state. Excessive production of nitric oxide can be studied by inhibiting the synthetic pathway of nitric oxide using both selective or specific nitric oxide synthase inhibitor or nonselective nitric oxide synthase inhibitor with respect to isoforms of nitric oxide.
\end{abstract}

S. Habib · A. Ali $(\bowtie)$

Department of Biochemistry, Faculty of Medicine, Aligarh Muslim University, Aligarh 202002, India e-mail: asifali_amu@rediffmail.com
Keywords Nitric oxide - Nitric oxide synthase $\cdot$ Nitric oxide inhibitors - Generation of nitric oxide - Cancer . Systemic lupus erythematosus - Direct and indirect effect of nitric oxide - Effect of nitric oxide on mitochondria

\section{Introduction}

The initial studies of the molecule (nitric oxide, NO) dates back to 1772, when Joseph Priestly called it "nitrous air," nitric oxide was first discovered as a colorless, toxic gas. Unfortunately, the tag of toxic gas and air pollutant continued until 1987, when it was shown to actually be produced naturally in the body. By 1987, nitric oxide's role in regulating blood pressure and relieving various heart ailments became well-established. Two years later, research revealed that nitric oxide is used by macrophages to kill tumor cells and bacteria. In 1992, nitric oxide was voted "Molecule of the Year". The importance of the molecule became front page news in 1998 when Louis J. Ignerro, Robert F. Furchgott and Ferid Murad were awarded the Nobel Prize for Medicine and Physiology for identifying nitric oxide as a signaling molecule. The discovery has opened up newer ways of treatment for millions of patients.

Nitric oxide (NO) plays an important role in the protection against the onset and progression of cardiovascular diseases. The cardioprotective roles of NO include regulation of blood pressure and vascular tone, inhibition of platelet aggregation and leukocyte adhesion, and prevention of smooth muscle cell proliferation. Reduced bioavailability of NO is thought to be one of the central factors common to cardiovascular disease, although it is unclear whether this is a cause of, or result of, endothelial dysfunction. Any disturbance in the bioavailability of NO 
leads to a loss of cardio protective actions and in some cases may even increase disease progression [1].

NO is composed of an atom each of nitrogen and oxygen such that seven electrons from nitrogen and eight electrons from oxygen are involved to form an uncharged molecule $(\mathrm{N} \equiv \mathrm{O})$. The high reactivity of NO is not due to the fact that it contains an unpaired electron having a half life of 2-30 s. If this were the case, how would tissues survive in presence of molecular oxygen with two unpaired electrons at a concentration of 20-200 $\mu \mathrm{M}$ [2]. Nitric oxide only reacts with those biological molecules that have unpaired orbital electrons e.g., other free radicals or transition metal ions. Since most of the biological molecules have completely filled orbitals, it renders nitric oxide unreactive towards them [3]. The reactivity of NO depends upon its physical properties, such as its small size, high diffusion rate, and lipophilicity. Moreover, the reaction products of nitric oxide, i.e. the related species, also react with biological molecules and may have toxic effect as well [4]. At low levels, NO can protect cells; however, at higher levels, it is a known cytotoxin, having been implicated in tumor angiogenesis and progression [5].

The biological reactions of nitric oxide can be divided into three main pathways [6].

\section{(a) Diffusion}

Nitric oxide trespasses the cell membrane by simple diffusion and reacts with cellular components. Once inside the cell, it may react with non-heme iron or quench tyrosyl radical of ribonucleotide reductase which may lead to inhibition of DNA synthesis [7, 8].

(b) Auto-oxidation to form $\mathrm{N}_{2} \mathrm{O}_{3}$ (nitrous anhydride)

Nitric oxide combines with nitrogen dioxide to form nitrous anhydride as given under:

$\mathrm{NO}+\mathrm{NO}_{2} \longleftrightarrow \mathrm{N}_{2} \mathrm{O}_{3}+\mathrm{H}_{2} \mathrm{O} \rightarrow 2 \mathrm{NO}_{2}{ }^{-}+2 \mathrm{H}^{+}$

\section{(c) Reaction with superoxide to form peroxynitrite}

Reaction of nitric oxide with superoxide in biological media yields peroxynitrite which is not a free radical as the new bond formed involves the free electrons on NO and $\mathrm{O}_{2}^{\bullet-}$. The peroxynitrite formed is a potent oxidant thus reacting with almost all biological molecules [9].

The peroxynitrite anion combine with carbon dioxide to form nitroso peroxycarbonate adduct, a known fastest reaction [10]. On decomposition it forms $\mathrm{NO}_{3}{ }^{-}$and $\mathrm{CO}_{2}$.

$\mathrm{ONOO}^{-}+\mathrm{CO}_{2} \rightarrow\left\{\mathrm{ONO}_{2} \cdot \mathrm{CO}_{2}^{-}\right\} \rightarrow \mathrm{NO}_{3}^{-}+\mathrm{CO}_{2}$

Nitric oxide also reacts with molecular oxygen. The reaction may take place in aqueous or in gas phase.
Although the product of both phases is same but its stability differs. The rate of the reaction is second order with respect to $\mathrm{NO}$ and first order with respect to $\mathrm{O}_{2}$ (Eq. 3) [11]. In gaseous phase, $\mathrm{NO}_{2}$ is a stable product of $\mathrm{NO}$ oxidation. But in aqueous solutions, $\mathrm{NO}_{2}$ give rise to $\mathrm{NO}, \mathrm{NO}_{3}{ }^{-}$[4]. NO reacts with molecular oxygen, which is present in much higher concentration than nitric oxide, to form peroxynitrite [12].

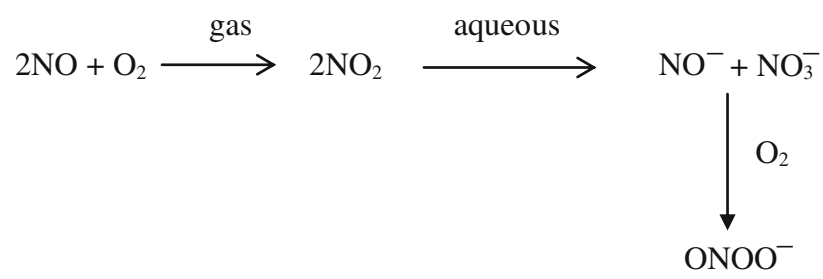

The nitroxyl anion $\left(\mathrm{NO}^{-}\right)$is also said to be endothelium derived relaxing factor, which is reactive but a short lived species [13]. It reacts with two nitric oxides to form nitrite and nitrous acid [14, 15]. The reaction intermediate $\left(\mathrm{ONNO}^{-}\right)$is quite similar to peroxynitrite. The only difference being that $\mathrm{ONNO}^{-}$will be one electron oxidant whereas peroxynitrite can be both one and two electron oxidant [2].

\section{Direct Effect of NO}

The kinetically fast reactions occurring physiologically are considered relevant [16]. NO does not react rapidly with amines or thiols but its reaction with metal complexes can be considered as relevant [16]. It reacts with metal complexes to form metal nitrosyls, e.g. Fe-NO complex which is quite stable. The radical is also capable of reacting with metallooxo as well as metal oxo complexes [16]. NO can also directly interact with hypervalent complex formed by agents such as $\mathrm{H}_{2} \mathrm{O}_{2}$ [17] and can reduce it to lower valency state.

$\mathrm{Fe}^{+(2,3)}+\mathrm{H}_{2} \mathrm{O}_{2} \rightarrow \mathrm{Fe}^{+(4,5)}=\mathrm{O}+\mathrm{H}_{2} \mathrm{O}$

$\mathrm{Fe}^{4+}=\mathrm{O}+\mathrm{NO} \rightarrow \mathrm{Fe}^{3+}+\mathrm{NO}_{2}^{-}$

The presence of NO results in scavenging superoxide which besides preventing enzyme inactivation also converts any ferrous oxyadducts to active ferric state. It is also reported that at low concentration of NO, direct effects will predominate, while at higher concentration indirect effects mediated by $\mathrm{NO} / \mathrm{O}_{2}^{\circ-}$ [16].

NO protects tissue from peroxide mediated damage by scavenging metal oxo species [18]. It has been shown to inhibit lipid oxygenase activity by reacting with nonheme iron at the active site [19]. A heme protein, 
cyclooxygenase, involved in the conversion of arachidonic acid to prostaglandin, and other related enzymes is also influenced by NO radical reactions and metal -NO interaction [19]. A possible mechanism accounted for cyclooxygenase inhibition by superoxide involves the reduction of ferric form to the inactive ferrous state. It has also been reported that $\mathrm{NO}$ generation results in nitrosative reactions at nucleophilic centers resulting in the formation of $S$ nitrosothiols [20]. Excess production of $\mathrm{NO}$ has been shown to mediate glutamate induced neuronal toxicity in cortical and striatal neurons culture [21]. NO mediated apoptosis has also been reported in murine peritoneal macrophages [22]. NO also react with oxyhemoglobin and results in the formation of met- $\mathrm{Hb}$ and $\mathrm{NO}_{3}{ }^{-}$.

$$
\begin{gathered}
\mathrm{Hb}-\mathrm{Fe}^{2+}\left(\mathrm{O}_{2}\right)+\mathrm{NO} \rightarrow \mathrm{Hb}-\mathrm{Fe}^{3+}+\mathrm{NO}_{3}{ }^{-} \\
\text {Rate constant } \mathrm{H}=3 \times 10.7 \mathrm{M}^{-1} \mathrm{~S}^{-1}
\end{gathered}
$$

$\mathrm{NO}$ also interacts with deoxy-Hb and met-Hb by binding to heme ion center. The binding is hindered by a water molecule coordinated to heme $\mathrm{Fe}^{3+}$ atom is case of met- $\mathrm{Hb}$ and it has been reported that the association rate constant is 100 fold less for ferrous deoxy-Hb [23]. Besides these reactions, NO plays important roles in tackling diseases of cardiovascular system by improving blood supply to heart muscle [24]. The anti-impotence drug Viagra exploites the signalling role of $\mathrm{NO}$ and increases blood flow into the corpus cavernosum of penis. NO acts as a signaling molecule in smooth muscle cell and neurons. The effect is due to activation of soluble guanyl cyclase (SGC). The formation of guanosine $3^{\prime}-5^{\prime}$ monophosphate (cGMP) from guanosine $5^{\prime}$-triphosphate is catalyzed by SGC which act as an intracellular messenger that connects the NO signal to the cellular response by activating specific protein kinases, phosphodiesterases and ion channels [9]. It has also been reported that binding of NO to heme moiety of soluble guanyl cyclase results in a pentacoordinate complex and the bond to the proximal histidine is lost [23] (Fig. 1).

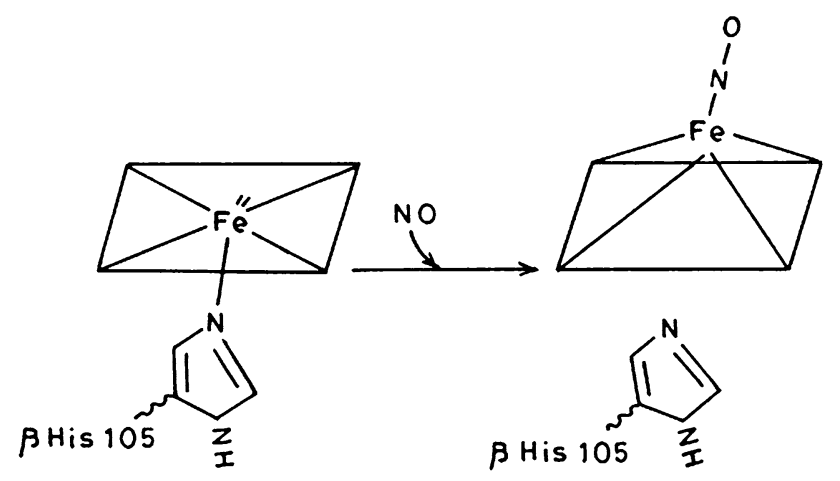

Fig. 1 Formation of pentacoordinate complex in heme moiety of guanyl cyclase
The production of nitric oxide in brain is very well established and it is quite different from other neurotransmitters like acetylcholine. The later, after the release from synapses, lasts for few milliseconds whereas NO persist for seconds, coupled with its rapid diffusion, enables it to encompass several million synapses [24].

The toxic effects of NO generally involve its oxidation products whereas $\mathrm{NO}$ alone is not capable of damaging DNA or ribosylate glyceraldehyde-3-phosphate dehydrogenase [25]. The radical can reversibly inhibit enzymes containing transition metal ions or free radical intermediate in their catalytic state [2]. NO in the micromolecular range can also reversibly inhibit cytochrome c oxidase $[26,27]$ which may result is leakage of superoxide from electron transport chain.

P53 is a protein involved in maintaining genome stability. Following exposure to DNA damaging agents rapid increase in p53 level occurs. Normally p53 has a short half life but DNA damage results in its accumulation in cells [28]. Following exposure to NO generating agents it has been shown that p53 is induced in both RAW 264.7 macrophages and RINm5F cells [29]. P53 accumulation proceed DNA fragmentation and hence apoptosis. NO inhibitors such as NMMA prevent both p53 accumulation and inducible NO generation thus leading to apoptosis [28]. NO mediates DNA damage by three mechanisms.

(a) Formation of nitrosoamines.

(b) Inhibition of DNA lesions repair systems which is also mediated by other genotoxic systems.

(c) Modification of DNA not directly by NO but by its oxidation products [30].

It has been reported that NO production is increased in patients with Systemic lupus erythematosus (SLE) [31]. The disorder is characterized by immune activated state where Inducible nitric oxide synthase (iNOS) level is increased in tissues like macrophages, splenic and renal tissues and consequently NO production [32]. Induction of iNOS occurs is response to cytokine production which is a non-specific event occurring in a wide variety of conditions like ulcerative colitis [33], psoriasis [34], arthritis [35], etc. Increased production of NO is not specific for SLE rather it represent an activated state of immune system.

To relate the role of NO in SLE, its site of production and quantum is of relevance. Patients with SLE showed upregulation of iNOS in normal appearing vascular endothelium. These endothelium also over express the soluble vascular adhesion molecules Intracellular cell adhesion molecule (ICAM-1), E-Selectin and Vascular cell adhesion molecule (VCAM) [36] as have been reported in active SLE [37]. Therefore, it appears that endothelium plays an active role in the localization and propagation of leukocyte and antibody-mediated inflammation [38]. Histological examination of ICAM-1 deficient mice revealed a 
significant reduction in glomerulonephritis and vasculitis of the kidney, lung and skin [39].

\section{Indirect Effect of NO}

The indirect effect of NO involves the reactions between superoxide and NO which leads to the production of peroxynitrite, a powerful oxidant (rate constant $-7 \times$ $10^{9} \mathrm{M}^{-1} \mathrm{~S}^{-1}$ ). Formation of $\mathrm{ONOO}^{-}$is governed by the relative amount of $\mathrm{NO}$ and superoxide produced and also on reaction of these radicals with other biological components. In presence of excess NO or superoxide, peroxynitrite gets converted to nitrogen dioxide, an inactive entity. An intracellular source of $\mathrm{ONOO}^{-}$is mitochondria where aerobic respiration results is production of superoxide and as NO concentration is higher in lipid layers than in cytosol [16], most $\mathrm{ONOO}^{-}$formed is in hydrophobic region. Its production is controlled by manganese, SOD as well as other antioxidants. It has also been reported that catechol-estrogens adducts or complexes are oxidized to quinones which can reduce oxygen to generate $\mathrm{O}_{2}^{\bullet-}$ ion or in presence of $\mathrm{NO}$ releasing compound leads to the production of $\mathrm{ONOO}^{-}$ [40]. Similarly, polyhydroxy aromatic compounds such as pyrogallol, and 1,4-hydroquinone autooxidize easily to form semiquinone radicals that react with dioxygen to generate $\mathrm{O}_{2}^{--}$which in combination with the NO releasing compound like SNP, DEA-NO, SPER-NO results in production of $\mathrm{ONOO}^{-}$[41] which is responsible for DNA damage (Fig. 2). The damaged DNA has been reported to be highly immunogenic, implicating its role in the production of antibodies in diseases like SLE and Cancer [42-44].

It has also been reported that quinone derivative of catechol-estrogen, which is produced by NO-mediated oxidation may form covalent adducts with nucleophilic groups of DNA [45]. Since human uterus and breast are site for hydroxylation of estrogens to form catecholestrogens [46], therefore a possible mechanism of hormonal carcinogenesis associated with these organs can be related with increased production of 4-hydroxyestradiol [47-49].

The peroxynitrite can also influence protein and enzyme function, this occurs by nitration of tyrosine residues in tissues thus contributing to pathological dysfunction [9]. The formation of 3-nitrotyrosine is contributed by many nitrogen oxide species such as peroxynitrite, nitrogen dioxide, nitrous acid, nitronium ion, etc. NO alone is not capable of nitrating tyrosine [50]. In addition to this, another way to tyrosine nitration involve myeloperoxidase which is secreted by monocytes and polymorphonuclear neutrophils under inflammatory conditions. Myeloperoxidase catalyzes<smiles>CC(CN[N+](=O)[O-])CC1(C)C(O)CCC2C3CCc4c(ccc(O)c4O)C3CCC21C</smiles>

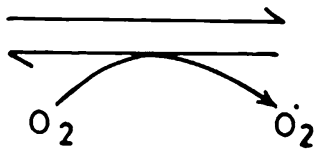<smiles>CC12CCC3C4=C(CCC3C1CCC2O)C(=O)C=CC4=O</smiles>

$+\mathrm{NO}$

$\mathrm{ONOO}^{-}$

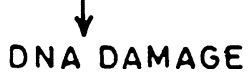

Fig. 2 Synergistic action of nitric oxide and catechol estrogen on DNA molecule 
the formation of hypochlorous acid which is capable of reacting with $\mathrm{NO}_{2}^{-}$to form $\mathrm{NO}_{2} \mathrm{Cl}$ (nitryl chloride) which is a potent nitrating agent [51].

The nitrated product 3-nitrotyrosine is found in many disease states such as chronic inflammation, atherosclerosis, acute lung injury, etc. [52, 53]. Nitration of cardiac actin impairs contractile function of heart in myocarditis. Whereas, if human neurofilament gets nitrated it interferes in the filament polymerization in amylotrophic lateral sclerosis [2]. The signal transduction cascade that depends on reversible phosphorylation of tyrosine is also disrupted by tyrosine nitration. Thus the occurrence of nitrotyrosinecontaining proteins in vivo should be regarded as a general indication of tissue damage induced by reactive nitrogen species such as peroxynitrite [54].

The indirect effect of NO can be further divided as oxidation and nitrosation. Those reactions in which reactive nitrogen oxide species (RNOS) donate NO to nucleophilic groups e.g. thiols and amines, lead to formation of nitrosonium adducts known as nitrosation reactions and condition termed as nitrosative stress. Whereas, when removal of electrons or hydroxylation reactions occurs, similar to those for reactive oxygen species (ROS), leading to oxidative stress, they are termed as oxidation reactions [55]. Both these reactions have different effects on biological systems (Fig. 3).

Activated macrophages derived $\mathrm{NO}$ and its oxidative metabolite, peroxynitrite were reported to play key notes is hepatocyte injury during inflammation and cause subsequent DNA damage is surviving hepatocytes. Stimulated macrophages in vivo express iNOS which produce high amount of NO and in turn RNOS, which is capable of mediating nitrosation of amines [56, 57], a condition encountered during chronic inflammation. Thus nitrosative stress under certain in vivo conditions can result in the formation of carcinogenic nitrosoamines [58, 59].

Both mammalian and bacterial cells when exposed to NO lead to deamination of guanine, cytosine and adenine

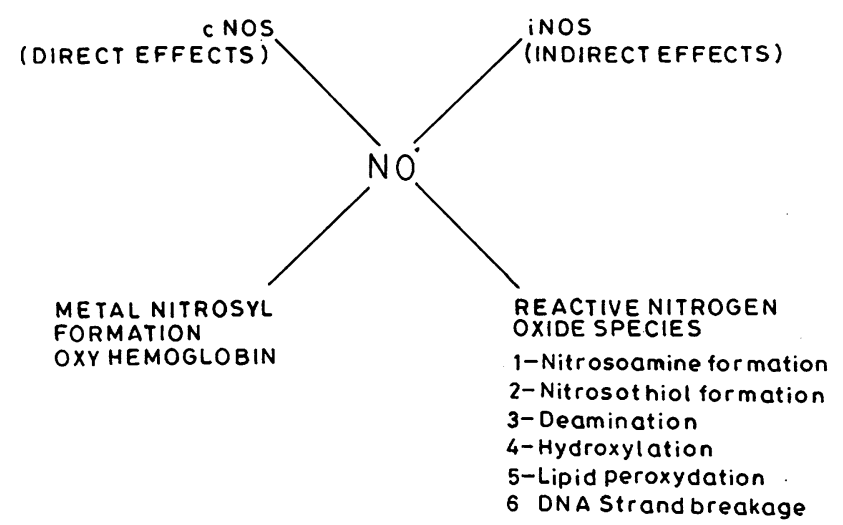

Fig. 3 Nitrosative and oxidative reactions of nitric oxide via nitrosative chemistry. This would lead to the conversion of cytosine to uracil, guanine to xanthine, adenine to hypoxanthine, methyl cytosine to thymine [60].

DNA damage also occurs by RNOS formed under oxidative stress. This damage is primarily caused due to formation of $\mathrm{ONOO}^{-}$[61]. It has been reported that SIN-1, a donor which is capable of generating both $\mathrm{NO}$ and superoxide, oxidizes guanine to $\mathrm{OH}-\mathrm{dG}$ [62]. Thus, there occurs a balance between oxidative and nitrosative stress [63]. It has also been reported that $\mathrm{NO}$ enhances the oxidative stress caused by $\mathrm{H}_{2} \mathrm{O}_{2}$ [64] and also reacts with other radicals such as lipid peroxides [2]. The endogenous production of NO leading to DNA damage generates both oxidative and nitrosative stress [65] (Fig. 4).

Nitric oxide can also play a protective role against oxidative damage by converting reactive species such as hydroxyl radical to less damaging and easily detoxified products [65]. Action of NO as pro- or antioxidant depends on relative production of $\mathrm{NO}$ and $\mathrm{O}_{2}^{--}$[66].

\section{Anti-tumor Effect of NO}

Though the direct or indirect reactions mediated by NO leading to modulation/damage to biological molecules have been summarised, the better side of NO should not be neglected. It acts as an immune effector generated by iNOS in macrophages, neutrophils, etc. in large quantities which kills or inhibits the growth of many pathogens including bacteria, fungi and parasites. NO is also capable of eliminating intracellular pathogens and blocking viral replication. It has also been reported that NO derived from leukocytes showed anti-tumor effect, it also upregulates tumor suppressor p53 gene [67]. Cells exposed to NO did not show appreciable mutation in p53 gene [68]. NO donors are capable of inhibiting angiogenesis, metastasis and tumor growth. Nitric oxide also inhibits DNA damage mediated by ROS and also inhibits hydroxylation reactions. Since high risk carcinogenic sites are those exhibiting prolonged expression of iNOS during chronic inflammation, NO generated from microphages, Kupffer cells, and NK cells is capable of inhibiting replication along with anti-tumor effect in the target cell [69, 70]. Murine embryonic liver cells, BNL CL.2, are capable of expressing iNOS in response to IFN- $\gamma$ thus accumulating NO.

In humans few tumors are caused by viruses e.g. liver cancer is caused by hepatitis B virus, cervical cancer by human papilloma virus, Adult $\mathrm{T}$ cell leukemia by human $\mathrm{T}$ cell leukemia virus. Interferon $\gamma$ is particularly important in limiting the spread of certain viral infections and capable of expressing iNOS. Increased concentration of NO in or near the target cell may act as tumoricidal since NO is capable of eliminating intracellular pathogens and blocking 
ENDOGENOUS SOURCES OF DNA DAMAGE

(Infection, metal storage disease, alcohol, dietry defeciency)

OXIDATIVE STRESS

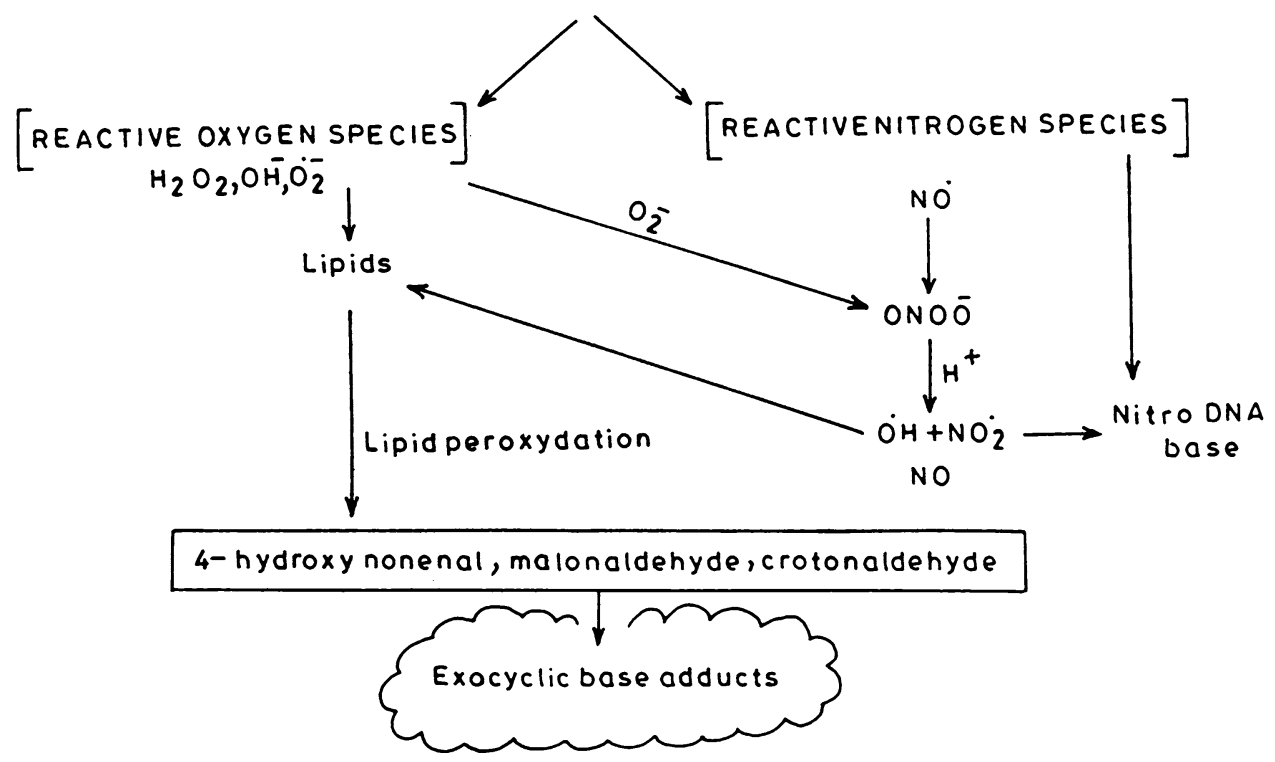

Fig. 4 Endogenous sources of DNA damage leading to oxidative stress

viral replication [71]. Nitric oxide is capable of protecting cell from apoptosis or mediating apoptosis depending upon the cell type e.g. NO protects rat ovarian follicles from atretic generation on one hand while on the other it induces apoptosis in tumor cells like in mastocytoma, sarcoma, melanoma [16]. NO is also reported to protect tissue form peroxide mediated damage by scavenging metallooxo species which are formed by oxidation of metal species or metal-oxygen species by $\mathrm{H}_{2} \mathrm{O}_{2}$ [72]. It is also been reported that animal subjects having tumorous growth acquire the ability through which their tumour tissues suppress the expression of iNOS and thus reduce the concentration of NO [73, 74]. Tumor growth is enhanced by accelerated angiogenesis by down regulating the production of vascular endothelial growth factor which is the mediator of angiogenesis [75]. Nitric oxide is also capable of suppressing metastasis by reducing intracellular stores of GSH $[76,77]$ or by blocking the adhesion of tumor cells to venular side of microcirculation [78]. It has also been reported that NO produced in vasculature of brain limits the spread of colon cancer to the brain [79]. Liver endothelial cells produce NO which curbs the metastases of melanoma cells to the lungs [80]. Though excessive production of NO is associated with tissue injury, it has been reported that endothelial NO production plays protective role in microvasculature [81]. NO is also reported to inhibit platelet aggregation and it reduces platelet adhesion to endothelial monolayers [82]. The defensive properties accounting for beneficial effect of NO in IL-2 induced injury include protection against tissue injury in myocardial ischemia reperfusion and adult respiratory distress syndrome [83, 84].

It is also reported that when cells were exposed to NO it resulted in DNA single strand breaks [85]. However, when purified DNA was exposed to NO at concentrations as high as $1.0 \mathrm{M}$, single stand breaks were not observed [86]. Nitric oxide is also reported to protect DNA against oxidative stress by inhibiting Fenton reaction of hydrogen peroxide which leads to single strand generation [87]. It has also been reported that $\mathrm{NO}$ in presence of a flavonoid having orthotrihydroxy group namely epigallocatechingallate or quercetogelin inhibits DNA damage by preventing formation of 8-nitroguanine in calf thymus DNA.

\section{Pro-tumor Effect of NO}

Carcinogenesis can be defined as a malignant transformation of a cell or group of cells. This process can be divided broadly into two stages, initiation and promotion. The initiation phase involves an irreversible modification of the genetic material of the cell caused by single exposure to any carcinogenic agent whereas promotion requires multiple exposures to the promoters to alter gene expression and produce a tumor. The promotion stage of carcinogenesis is irreversible. Cancer has multifactorial aetiology 
which includes genetic and environmental factors. The common environmental factors are tobacco chewing, smoking, high fat diet, contaminants, also the occupational exposures to agents like, arsenic, cadmium, chromium, etc. Other environmental factors include sunlight, radiation, pesticides, steroidal medications, etc. It is well known that most of the exogenous carcinogens act via production of reactive oxygen or reactive nitrogen species. The reactive oxygen species are generated both physiologically and pathologically in mammals and induce many kind of cellular damage [88] including DNA damage [89]. Since DNA plays a central role in information transfer, attention has focussed on oxidative damage as significant source of mutations that lead to cancer and other human pathologies [90]. The possible role of ROS modified human DNA in cancer has been indicated from our studies and it has been found that binding of circulating antibodies in cancer sera was much stronger with ROS modified DNA than native DNA. ROS modified DNA has been shown to be a better inhibitor of naturally occurring antibodies in majority of cancer patients than native human DNA [91], reiterating the enhanced recognition of ROS-DNA.

Excess production of $\mathrm{NO}$ has been linked to endogenous human carcinogenesis. Induction of apoptosis by NO has also been observed in culture of macrophages and pancreatic $\beta$ cells. Macrophages exposed to nitric oxide exhibited typical morphology and showed DNA fragmentation indicating apoptotic cell death [28]. NO also induced cell death and showed toxic effects in two different cell lines, viz., CHO-AA8 (Chinese hamster ovary cells) and TK6 (human lymphoblastoid cells) highlighting the role of $\mathrm{NO}$ in the onset of mutagenesis and cell death and the involvement of these processes in cancer and inflammatory diseases [92]. Nitric oxide also showed genotoxic effects by abolishing cell growth which is a valuable parameter sensitive to different kinds of damage, e.g. membrane damage, energy depletion, organelle damage and enzyme release, etc. [93]. Peroxynitrite is short lived with $t_{1 /}$ $2<1 \mathrm{~s}$. and is capable of oxidative damage of wide range of biological molecules e.g. nucleic acids, lipids, thiols, etc. [94]. At pH 6.8 its conjugate acid $\mathrm{ONOOH}$ can diffuse through membranes and cause damage at a distance from its site of synthesis [95].

It is well known that solid tumors require tumor angiogenesis for their growth i.e. the tumorous cells should be well supplied with oxygen, nutrients and growth factors. Another important feature of malignancy is enhanced vascular permeability which is regulated by endothelial cell production of vasoactive substances. The endothelial cells synthesize NO by Endothelial nitric oxide synthase (eNOS) which helps in vascular permeability and relaxation [96]. Various tumours over express NOS [97, 98]. A study between the relationship of malignancy and eNOS expression in endothelial cells of tumor vessels showed that astrocytic tumor vessels possess higher level of nitric oxide than do normal vessels and found that there was significant correlation with the proliferative potential and eNOS expression in tumor vessels [99]. Several studies have suggested that NO and its reactive derivatives e.g. $\mathrm{ONOO}^{-}$were found to be elevated in infection and inflammation and plays important role in carcinogenesis $[100,101]$. The carcinogenic effect of NO may be due to its cytotoxic potential which lead to reduced cell viability [93]. As stated earlier, $\mathrm{NO}$ per se is not capable of reacting with biomolecules; only its reaction products lead to the production of RNOS e.g. $\mathrm{N}_{2} \mathrm{O}_{3}$ or $\mathrm{ONOO}^{-}$which can result in DNA lesions.

The type of mutation under oxidative and nitrosative stresses differ [102]. Oxidative stress mediate DNA damage by the formation of peroxynitrile. It has been shown that DNA strand breaks were generated when plasmid DNA was incubated with NO-donor compound and polyhydroxy aromatic compounds. On autooxidation of polyhydroxy aromatic component produce semiquinones which react with dioxygen to generate $\mathrm{O}_{2}^{\bullet-}$

Nitrosative stress leads to the formation of nitrosoamines e.g. RNOS generated from acidic nitrite is potentially carcinogenic in stomach [103, 104]. Nitrosamines are formed under conditions of inflammation which can lead to cancer [100]. NO also enhances tumor production by increasing the production of prostaglandin, PGE2 which increases the permeability of tumor vasculature and thus facilitate angiogenesis. Further tumor growth is supported by increased uptake of nutrients [105, 106]. Cells lacking $\mathrm{Cu}, \mathrm{Zn}-\mathrm{SOD}$ are reported to be more susceptible to NO and $\mathrm{ONOO}^{-}[107,108]$. It has been reported that large amount of $\mathrm{ONOO}^{-}$causes necrosis where as small amounts produce apoptosis [109]. Nitric oxide also causes cellular energy deficit through DNA damage [110]. NO inhibits ribonucleotide reductase which results in impaired DNA synthesis as deoxyribonucleotides are no more available [111]. Since $\mathrm{ONOO}^{-}$causes DNA breaks this leads to activation of poly (ADP-ribose) polymerase to repair the damaged DNA $[112,113]$. The activated PARP transfers about $100 \mathrm{ADP}$ ribose moieties from $\mathrm{NAD}^{+}$to nuclear proteins e.g. histones and PARP itself $[112,114]$. ADP ribose polymers thus formed are degraded by glycohydrolases followed by $\mathrm{NAD}^{+}$resynthesis which is a futile cycle and depletes ATP [114].

Reactive nitrogen oxide species have high affinity towards amino acid with thiol groups and therefore are capable of inhibiting enzymes having thiol residues required for their function [115] e.g. DNA alkyl transferases, required for repair of DNA lesions induced by alkylation, are inhibited by nitrosating its thiol residue in the active site [116, 117]. Other DNA repair enzyme inhibited by RNOS is DNA ligase. T4 DNA ligase contains 
lysine in partially deprotonated state which is nitrosated by NO [30]. Other DNA repair enzyme inhibited by nitrosating thiols in formamidopyrimidine glycosylase which has zinc finger motif required for its activity. Upon nitrosation, $\mathrm{Zn}$ is removed resulting in enzyme inactivation [118].

\section{Effect of NO on Mitochondria}

Interaction of $\mathrm{NO}$ with mitochondria occurs is many ways. NO synthesis may occur in organelle itself or NO produced outside may diffuse inside. NO may affect mitochondria by three main pathways.

(a) Inactivation of mitochondrial enzymes which is irreversible

(b) Induction of mitochondrial permeability transition

(c) Inhibition of respiration which is reversible [110].

Therefore, effect on mitochondria mediated by NO occurs both by irreversible and reversible means. It has been shown that NO is capable of nitrosating critical thiol residues on creatinine phosphokinase which is irreversible and de-energizes mitochondria thus disrupting its ATP supply [119-121]. Nanomolar concentrations of NO are capable of reversible binding to heme as of cytochrome $\mathrm{c}$ oxidase [122]. This direct interaction of NO with cytochrome $\mathrm{c}$ is due to cNOS inhibition of mitochondrial respiration [26, 123]. Under aerobic conditions it has been shown that electron transport chain participate in forming superoxide which can then react with $\mathrm{NO}$ to form $\mathrm{ONOO}^{-}$ [123]. In addition, $\mathrm{ONOO}^{-}$formed outside mitochondria diffuses into the matrix. The increased concentration of $\mathrm{ONOO}^{-}$inactivates $\mathrm{Mn}-\mathrm{SOD}$ resulting in increase of $\mathrm{O}_{2}^{\bullet-}$ level and hence activating a destructive cascade of $\mathrm{NO}$ [124] which includes:

(1) Irreversible damage of enzymes of citric acid cycle e.g. aconitase, iron-sulphur centers, etc. [125, 126].

(2) Inhibition of glycolysis by inactivating glyceraldehyde-3-phosphate dehydrogenase thus impairing ATP synthesis.

(2) Under inflammatory conditions, NADH:ubiquinone oxidoreductase (complex I) and succinate:ubiquinone oxidoreductace (complex II) are irreversibly inhibited by NO [127].

It has been found that NOS is present in mitochondria and that under normal conditions, production of $\mathrm{NO}$ is well regulated [2]. Induction of mitochondrial permeability transition is mainly caused by $\mathrm{ONOO}^{-}$which oxidizes thiols and NADPH of mitochondria and induces $\mathrm{Ca}^{2+}$ efflux [128, 129] along with oxidative efflux. As a consequence, $\mathrm{Ca}^{2+}$ homeostasis is disrupted [130, 131]. Mitochondrial decrease in membrane potential in induction of permeability transition leads to increase in cytoplasmic $\mathrm{Ca}^{2+}[131,132]$. This permeability transition is accompanied by the formation of a protein pore in mitochondrial inner membrane resulting is the leakage of its contents [131, 133].

Current evidence indicates that irreversible modification of iron binding cysteine residues releases metal and disrupts $\mathrm{FeS}$ structure. This is caused by $\mathrm{ONOO}^{-}$rather than by NO [126, 134]. Peroxynitrite damages membranes by hydrogen abstraction from polyunsaturated fatty acids which results is lipid peroxidation [135]. $\mathrm{ONOO}^{-}$also consumes biological antioxidants [136] enhancing the chances of mitochondrial damage.

The role of NO in membrane damage and necrosis was also demonstrated and the leakage of lactate dehydrogenase in TKG and CHO-AA8 cell lines both treated with NO has been observed. However, no LDH leakage was observed before $24 \mathrm{~h}$ in TK6 cell and $48 \mathrm{~h}$ in CHO-AA8 cells [137]. It has been reported that inactivation of mitochondria by $\mathrm{ONOO}^{-}$in vitro is remarkably similar to the respiratory inhibition observed in cultured tumor cells caused by activated macrophages [138]. If the internal nitric oxide concentration approaches that of mitochondrial superoxide dismutase the superoxide is reported to largely react with the nitric oxide and form peroxynitrite that would injure mitochondria irreversibly [139, 140].

\section{Interaction with Metal Ions}

Nitric oxide is capable of directly reacting with metal complexes or oxo complexes. The product of reaction is metal nitrosyls. Reaction of NO with metals may be categorized as:

(A) Direct reaction of NO with metals

(B) Reaction of $\mathrm{NO}$ with dioxygen metal complexes

(C) Reaction of NO with oxo-complexes.

The reaction of nitric oxide to form metal nitrosyls is involved is both regulatory and cytotoxic actions [141]. Nitric oxide reacts into oxyhemoglobin. (oxy-Hb) to form met- $\mathrm{Hb}$ and $\mathrm{NO}_{3}{ }^{-}$(Eq. 7). The reaction is second order having a rate constant of $3 \times 10^{-7} \mathrm{M}^{-1} \mathrm{~S}^{-1}$.

$\mathrm{Hb}-$ FeII $\left(\mathrm{O}_{2}\right)+\mathrm{NO} \rightarrow \mathrm{Hb}-\mathrm{FeIII}+\mathrm{NO}_{3}{ }^{-}$

A variety of cellular components present inside the cell e.g. cytochrome c oxidase and cytochrome $\mathrm{P} 450$ is able to bind with NO which may result in inhibition of mitochondrial respiration. Since nitric oxide synthase is also present in mitochondria, it may increase the production of NO under inflammatory stressed state. NO has great affinity for iron and heme proteins due to the presence of porphyrin ligands [141]. Reactions of NO with zinc and 
copper containing proteins have also been reported, an important class of DNA binding protein induce zinc finger motifs [142]. Since zinc finger motif contain two to four cysteine residues and up to two histidine residues e.g. formamidopyrimidine-DNA glycosylase (Fpg protein). The protein repairs oxidative damage to guanine. NO under aerobic conditions inhibits Fpg [30]. Another example of reaction of $\mathrm{NO}$ with metal centers is reaction of soluble guanyl cyclase which is activated by binding of NO to ferrous heme iron resulting in generation of cGMP and transduction of NO signal [141].

Nitric oxide forms iron nitrosyl complexes by binding to iron-sulfur clusters e.g. NO is capable of inactivating aconitase due to its direct interaction with the enzymes heme iron nitrosyl complex [9]. These reactions of NO with metals generally involve covalent interactions. In addition, various metal oxygen complexes e.g. reaction of $\mathrm{NO}$ and oxyhemoglobin to form met-hemoglobin and nitrate (Eq. 7) also occur. This is one of the primary detoxification mechanisms of NO.

Nitric oxide also rapidly reacts with hypervalent metal complexes i.e. metallooxo species which are formed by the oxidation of metals or metal oxygen complexes by e.g. $\mathrm{H}_{2} \mathrm{O}_{2}$ [30]. Nitric oxide reacts with these hypervalent species and results in conversion of hypervalent complex to lower valent state thereby scavenging the metallooxo species and protecting cells from peroxide mediated damage [18]. Formation and scavenging the metallooxo species can be presented as under:

$$
\begin{aligned}
& \mathrm{Fe}^{(2,3)}+\mathrm{H}_{2} \mathrm{O}_{2} \rightarrow \mathrm{Fe}^{(4,5)+}=\mathrm{O}+\mathrm{H}_{2} \mathrm{O}_{2} \\
& \mathrm{Fe}^{4+}=\mathrm{O}+\mathrm{NO} \rightarrow \mathrm{Fe}^{3+}+\mathrm{NO}_{2}{ }^{-}
\end{aligned}
$$

The high reactivity of NO with diverse chemical groups and with transition metal ions is used as a guide line for designing drugs used as NO scavengers [143]. Many coordination complexes that are Ruthenium complexes are proposed as efficient NO scavengers e.g. JM-1226 a Ruthenium coordination complex has been shown in the recovery of rat from sepsis, another NO scavenger used is 2 Phenyl-4,4,5,5 tetramethylimidazolin1-oxyl-3 oxide (PTIO).

\section{NOS Enzymes}

Biosynthesis of nitric oxide takes place by the conversion of L-arginine to L-citrulline catalyzed by nitric oxide synthases. The enzyme has three isoforms. NOS1 or neuronal nitric oxide synthase (nNOS). NOS2 or inducible nitric oxide synthase (iNOS) and NOS3 endothelial nitric oxide synthase (eNOS). Among these, the first isoform has been purified and cloned [30]. Each isoform is a product of distinct gene [144]. Broadly speaking isoforms of nitric oxide synthase may be categorised as constitutive (cNOS) and inducible nitric oxide synthase (iNOS). Constitutive NOS is calcium dependent and continuously present whereas iNOS is $\mathrm{Ca}^{2+}$ independent and is expressed only after cytokine exposure [145]. Based on this category nNOS and eNOS are constitutively expressed and require elevated levels of $\mathrm{Ca}^{2+}$ along with activation of calmodulin to produce NO for brief period of time [146]. iNOS is induced by cytokines in almost every cell and generates locally high level of NO for prolonged periods of time [30]. It is mainly expressed in macrophages, neutrophils and epithelial cells. It has also been reported that in mice, estrogen and progesterone-induced iNOS expression is different in different cell population i.e. estrogen induces it in myometrial mast cell whereas progesterone induces it in epithelial cells.

It is also reported that cNOS are employed in physiological regulation within cardiovascular and nervous system where they produce low concentration of $\mathrm{NO}-1.0 \mu \mathrm{M}$ in cardiovascular and $5 \mu \mathrm{M}$ in neurological systems whereas iNOS produce $\mathrm{NO}$ achieving concentrations equal to $10 \mu \mathrm{M}$ [141].

\section{Inducible NOS}

This is type 2 NOS and is induced by inflammatory stimuli e.g. cytokines or lipopolysaccharides. It is mainly expressed is macrophages and possess tightly bound calmodulin [141]. It is also reported that iNOS is not only present is activated macrophages but its synthesis can be induced in glial cells, liver and cardiac muscle.

\section{Endothelial NOS}

It is constitutively expressed in endothelial lining of blood vessels and depends on $\mathrm{Ca}^{2+}$. The NO produced by eNOS diffuses into smooth muscle cells of blood vessel and elicits cGMP dependent smooth muscle relaxation and thus increasing blood flow.

\section{Neuronal NOS}

Neuronal nitric oxide synthase is constitutively expressed in post synaptic terminals of neurons and is $\mathrm{Ca}^{2+}$ dependent. It is activated by $\mathrm{Ca}^{2+}$ influxes caused by binding of neurotransmitter glutamate, to receptor in cell membrane. nNOS is also activated by membrane depolarization through opening of voltage gated $\mathrm{Ca}^{2+}$ channels [9].

The synthesis of NO by nitric oxide synthases takes place by conversion of L-arginine to L-citrulline via the formation of $\mathrm{N}^{\mathrm{G}}$-hydroxy-L-arginine (Fig. 5). Therefore, NOS utilize L-arginine, NADPH and oxygen to produce nitric oxide. Nitric oxide synthase enzyme is an heme iron 
Fig. 5 Synthesis of nitric oxide from L-arginine

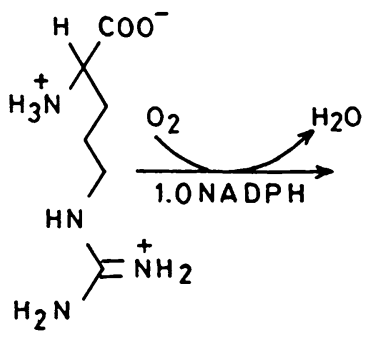

L-ARGININE

dependent tetrahydrobiopterin enzyme where tetrahydrobiopterin binds far away and on the wrong side of porphyrin to act as hydroxylating cofactor at distal side of heme-iron center [9]. Other enzymes that use tetrahydrobiopterin are e.g. phenyl monooxygenase, tyrosine-3monooxygenase, tryptophan-5-monooxygenase, etc. In these cases the coenzyme is directly involved in hydroxylation of substrate and which then gets oxidized to dihydrobiopterin. The dihydrobiopterin is recycled to tetrahydrobiopterin by dihydropteridine reductase.

Nitric oxide synthase enzyme in its active form is a homodimer where each subunit is composed of C-terminal reductase and N-terminal oxygenase domain. It is also reported that the isolated oxygenase domain remain homodimeric whereas isolated reductase domain is monomeric indicating that the two subunits are joined by their oxygenase domains. The oxygenase domain contains a heme group and one binding site for tetrahydrobiopterin and L-arginine. Whereas, the reductase domain of nitric oxide synthase has binding sites for either of the one molecule of Flavin mononucleotide (FMN), Flavin adenine dinucleotide (FAD) and NADPH [144]. Between the reductase and oxygenase domain there is a binding site for calmodulin. In case of nNOS and eNOS only $\mathrm{Ca}^{2+}$-calmodulin complex can activate the enzyme whereas is case of iNOS, it is already bound to calmodulin and is fully active. Calmodulin is reported to improve electron flow from NADPH to flavins and also facilitates electron transfer from FMN to heme [8]. The flow of electrons in nitric oxide synthase domains are represented in Fig. 6.

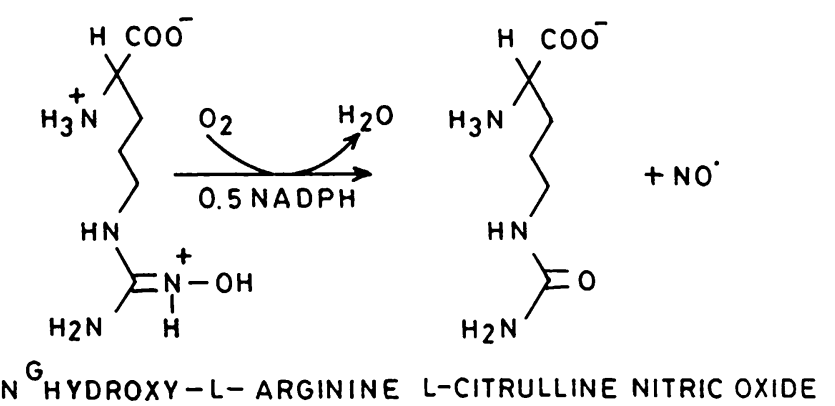

\section{Inhibitors of NO}

In order to study the over production of NO, inhibitors of NOS have been synthesized and investigated for their probable role in controlling the over production of NO under disease condition. Since L-arginine is a naturally occurring substrate for NO, analogs of L-arginine have been used as competitive NOS inhibitors. These inhibitors were nonselective with reference to isoforms of nitric oxide synthase e.g. $N$-monomethyl-L-arginine and nitro-L-arginine methyl ester [143]. Among the synthetic analogs of L-arginine only homo L-arginine and agmatine are active (Fig. 7).

It is reported that removal of $\alpha$-aminopentanoic acid part of $\mathrm{N}^{\mathrm{G}}$ methyl-L-arginine (L-NMA), $\mathrm{N}^{\mathrm{G}}$ amino-L-arginine
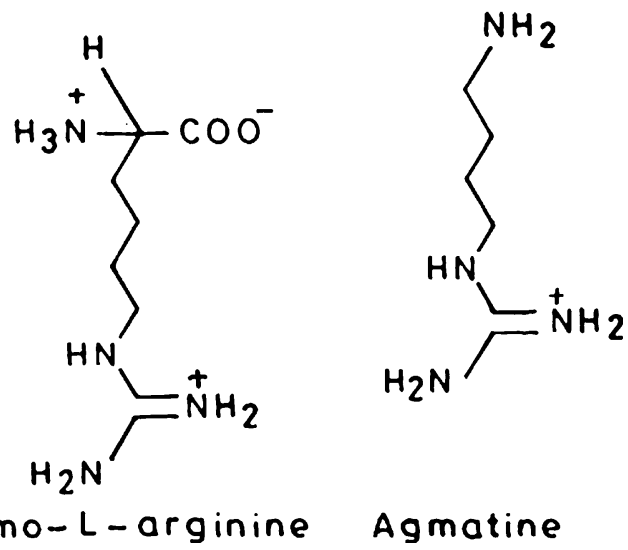

\section{Homo-L-arginine Agmatine}

Fig. 7 Competitive inhibitors of nitric oxide synthase enzyme
Fig. 6 Flow of electrons in nitric oxide synthase domain from FMN to heme
REDUCTASE DOMAIN

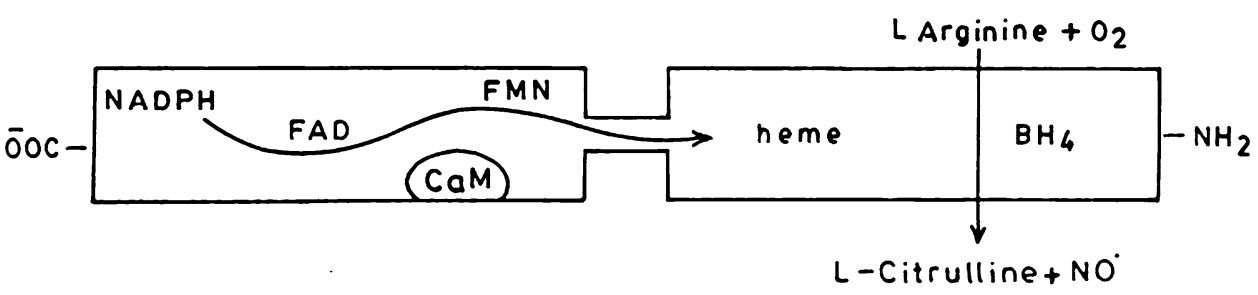


Table 1 Characteristics of NOS inhibitors

\begin{tabular}{lll}
\hline Inhibitor & Specificity & Clinical importance \\
\hline L-NIL & iNOS & Effective in arthritis and leishmaniasis \\
S-methylisothiourea, 4-amino-tetrahydrobiopterin & iNOS & NOS is most sensitive towards inhibition during de novo protein synthesis \\
Galaxo-Wellcome compound 1400 W & iNOS & Rapid reversibility and low potency Ki $\approx 2-50 \mu \mathrm{M}$ \\
1-Amino-S-methylisothiourea & iNOS & - \\
7-Nitroindazole & nNOS & Experimental stroke \\
Astra Arcus Compound ARL 17477 & & Infracts caused by temporary occlusion of middle cerebral artery in rats \\
\hline
\end{tabular}<smiles>NC(=Nc1ccc(CCNCc2cccc(Cl)c2)cc1)c1cccs1</smiles>

ARL 17477<smiles>CC(=N)NCc1cccc(CN)c1</smiles>

Fig. 8 Specific inhibitors of neuronal nitric oxide synthase

(L-NAA) and $\mathrm{N}^{\mathrm{G}}$ nitro-L-arginine (L-NNA), also the ana$\operatorname{logs}$ of L-arginine, results in the formation of guanidine which looses binding affinity [9]. Some of the analogs of L-arginine also exhibit irreversible inactivation of NOS in presence of oxygen and NADPH e.g. L-NMA, $\mathrm{N}^{\varepsilon}$ iminoethyl-L-Lysine (L-NIL), $\mathrm{N}^{8}$ iminoethyl-L-ornithine (L-NIO) i.e. inhibition is mechanism based.

Along with the non-specific inhibitors of NOS, many isoform specific inhibitors are also available. e.g. 7-nitroindazole and aminoguanidine are inhibitors of nNOS and iNOS, respectively [143]. The importance of these isoenzyme specific inhibitors is that they inhibit selective NO biosynthesis rather than suppressing whole NO biosynthesis (Table 1). L-NIL is an exception with 30 folds more specificity towards iNOS [147]. Among these inhibitors Galaxo Wellcome compound $1400 \mathrm{w}$ ( $N$-(3-aminomethyl) benzyl) acetamide) is most selective iNOS inhibitor and Astra Arcus compound ARL 17477 is most selective for nNOS (Fig. 8).

In higher vertebrates nitric oxide has key roles in maintaining homeostasis and in vascular smooth muscle, neurons and the GI tract. It has a definite role in regulating all aspects of our lives from walking, digestion, sexual function, pain perception and pleasure, memory recall and sleeping. Finally, the way it continues to function in our bodies will influence how we degenerate with age. It has a likely role in our deaths through cardiovascular disease, stroke, diabetes and cancer. Our ability to control NO signaling and to use NO effectively in therapy must therefore have a major bearing on the future quality and duration of human life [148].

\section{References}

1. Naseem KM. The role of nitric oxide in cardiovascular diseases. Mol Asp Med. 2005;26:33-65.

2. Beckman JS, Koppenol WH. Nitric oxide, superoxide and peroxynitrite: the good the bad and the ugly. Am J Physiol. 1996; 271:C1424-37.

3. Padmaja S, Huie RE. The reactions of nitric oxide with organic peroxyl radical. Biochem Biophys Res Commun. 1993;195: 539-44.

4. Hughes MN. Chemistry of nitric oxide and related species. Methods Enzymol. 2008;436:3-19.

5. Paradise WA, Vesper BJ, Goel A, Waltonen JD, Altman KW, Haines GK, Radosevich JA. Nitric oxide: perspectives and emerging studies of a well known cytotoxin. Int J Mol Sci. 2010;11:2715-45.

6. Tamir S, Burney S, Tannenbaum SR. DNA damage by nitric oxide. Chem Res Toxicol. 1996;9:821-7.

7. Kwon NS, Stuehr DJ, Nathan CF. Inhibitor of tumor cell ribonucleotide reductase by macrophage-derived nitric oxide. J Exp Med. 1991;174:761-7.

8. Roy B, Lepoivre M, Henry Y, Fontecave M. Inhibition of ribonucleotide reductase by nitric oxide derived from thionitrites: reversible modifications of both subunits. Biochemistry. 1995;34:5411-8.

9. Pfeiffer S, Mayer B, Hemmens B. Nitric oxide: chemical puzzles posed by a biological messenger. Angew Chem Int Ed. 1999;38:1714-31.

10. Uppu RM, Squadrito RM, Pryor WA. Acceleration of peroxynitrite oxidation by carbon dioxide. Arch Biochem Biophys. 1996;327:335-43.

11. Olbregts J. Tetramolecular reaction of nitrogen monooxide and oxygen: a still unsolved problem. Int J Chem Kinet. 1985;17: 835-48.

12. Hughes MN, Nicklin HG, Sackrule WAC. The chemistry of peroxonitrities. Part III. The reaction of peroxynitrite with nucleophiles in alkali and other nitrite producing reactions. J Chem Soc A. 1971;23:3722-5.

13. Fukuto JM, Chiang K, Hszieh R, Wong P, Chaudhri G. The pharmacological activity of nitroxyl: a potent vasodilator reversing hypoxic pulmonary vasoconstriction. Circulation. 1991;83:2038-47.

14. Seddon WA, Fletcher JW, Sopchyshyn FC. Pulse radiolysis of nitric oxide in aqueous solution. Can J Chem. 1973;51:1123-30. 
15. Seddon WA, Young MJ. Pulse radiolysis of nitric oxide in aqueous solution. Can J Chem. 1970;48:393-4.

16. Wink DA, Mitchel JB. Chemical biology of nitric oxide: insights into regulatory cytotoxic and cytoprotective mechanisms of nitric oxide. Free Radic Biol Med. 1998;25:434-56.

17. Puppo A, Halliwell B. Formation of hydroxyl radicals from hydrogen peroxide in presence of iron: is hemoglobin a biological Fenton reagent? Biochem J. 1998;249:185-90.

18. Kanner J, Harel S, Granit R. Nitric oxide as an antioxidant. Arch Biochem Biophys. 1991;289:130-6.

19. Kanner J, Harels S, Ganit R. Nitric oxide an inhibitor of lipid oxidation by lipoxygenase, cyclooxygenase and hemoglobin. Lipids. 1992;27:46-9.

20. Mohr S, Stamler JS, Brune B. Mechanism of covalent modification of glyceraldehyde-3-phosphate dehydrogenase at its active site thiol by nitric oxide, peroxynitrite and related nitrosating agents. FEBS Lett. 1994;348:223-7.

21. Dawson VL, Dawson JM, London ED, Bredt DS, Snyder SH. Nitric oxide mediates glutamate neurotoxicity in primary cortical cultures. Proc Natl Acad Sci USA. 1991;88:6368-71.

22. Albina JE, Cui S, Mateo B, Reichner JS. Nitric oxide mediated apoptosis in murine peritoneal macrophages. J Immunol. 1993; 150:5080-5.

23. Stone JR, Sands RH, Dunham WR, Marletta MA. Electron paramagnetic resonance optical evidence for the formation of penta coordinate nitrosyl complex on soluble guanylate cyclase. Biochem Biophys Res Commun. 1995;207:572-7.

24. Yoshie Y, Oshima H. Synergistic action of DNA strand breakage caused by nitric oxide together with catecholamines: implications for neurodegenerative diseases. Chem Res Toxicol. 1997;10:1015-22.

25. Dimmeler S, Lottspeich F, Brune B. Nitric oxide causes ADP ribosylation and inhibition of glyceraldehyde-3-phosphate dehydrogenase. J Biol Chem. 1992;267:16771-4.

26. Cleeter MWJ, Cooper JM, Darley-Usmar VM, Moncada S, Schapira AHV. Reversible inhibition of cytochrome $c$ oxidase, the terminal enzyme of the mitochondrial respiratory chain by nitric oxide. FEBS Lett. 1994;345:50-4.

27. Gow JP, Spruell C, Chen J, Gunn C, Ischiropoulos H, Tsai M, Smith CD, Radi R, Koppenol WH, Beckman JS. On the pH dependent yield of hydroxyl radical products from peroxynitrite. Free Radic Biol Med. 1994;16:331-8.

28. Nicotera P, Bonfoco E, Brune B. Mechanisms for nitric oxide induced cell death: involvement of apoptosis. Adv Neuroimmunol. 1995;5:411-20.

29. Me Bmer UK, Lapetina EG, Brune B. Nitric oxide induced apoptosis in RAW 264.7 macrophages is antagonized by protein kinase $\mathrm{C}$ and protein kinase A activating compounds. Mol Pharmacol. 1995;47:757-65.

30. Wink DA, Vodovotz Y, Laval J, Laval F, Dewhirst MW, Mitchell JB. The multifaceted roles of nitric oxide in cancer. Carcinogenesis. 1998;19:711-21.

31. Belmont HM, Levartovsky D, Goel A, Amin A, Giorno R, Rediske J, Skovron ML, Abramson SB. Increased nitric oxide production accompanied by the up regulation of inducible nitric oxide synthase in vascular endothelium from patients with systemic lupus erythematosus. Arthritis Rheum. 1997;40: 1810-6.

32. Weinberg JW, Granger DL, Pisetsky DS, Seldin MF, Misukonis MA, Mason SN, Pippen AM, Ruiz P, Wood ER, Gilkeson GS. The role of nitric oxide in the pathogenesis of spontaneous murine autoimmune disease: increased nitric oxide production and nitric oxide synthase expression in MRL-Lpr mice and reduction of spontaneous glomerulonephritis and arthritis by orally administered NG-monomethyl-L-arginine. J Exp Med. 1994;179:651-60.
33. Middleton SJ, Shorthouse M, Hunter JO. Increased nitric oxide synthesis in ulcerative colitis. Lancet. 1993;341:465-6.

34. Kolb-Bachofen V, Fehsel K, Miche G, Ruzicka T. Epidermal keratinocyte expression of inducible nitric oxide synthase in skin lesions of psoriasis vulgaris. Lancet. 1994;344:139-42.

35. Gorbunov N, Esposito E. Nitric oxide as a mediator of inflammation. Int J Immunopathol Pharmacol. 1993;6:67-75.

36. Belmont HM, Buyon J, Giorno R, Abramson S. Up regulation of endothelial cell adhesion molecules characterizes disease activity in systemic lupus erythematosus: the Shwartzman phenomenon revisited. Arthritis Rheum. 1994;37:376-83.

37. Spronk PE, Bootsma H, Huitema MG, et al. Levels of soluble VCAM-1, soluble ICAM-1 and soluble E-selectin during disease exacerbations in patients with systemic lupus erythematosus (SLE): a long term prospective study. Clin Exp Immunol. 1994;97:439-44.

38. McMurray RW. Adhesion molecules in autoimmune disease. Semin Arthritis Rheum. 1996;25:215-33.

39. Bullard DC, King PD, Hicks MJ, Dupont B, Beaudet AL, Elkon KB. Intracellular adhesion molecule-1 deficiency protects MRL/ MpJ-Fas Lpr mice from early lethality. J Immunol. 1997;715: 2058-67.

40. Yumiko Y, Hiroshi O. Synergistic induction of DNA strand breakage by catechol estrogens and NO: implications for hormonal carcinogenesis. Free Radic Biol Med. 1998;24:341-8.

41. Yumiko Y, Hiroshi O. Nitric oxide synergistically enhances DNA strand breakage induced by polyhydroxy compounds but inhibits that induced by Fenton reaction. Arch Biochem Biophys. 1997;342:13-21.

42. Habib S, Moinuddin, Ali R. Acquired antigenicity of DNA after modification with peroxynitrite. Int J Biol Macromol. 2005;35: 221-5.

43. Habib S, Moinuddin, Ali R. Peroxynitrite modified DNA: a better antigen for systemic lupus erythematosus anti-DNA autoantibodies. Biotechnol Appl Biochem. 2006;43:65-70.

44. Habib S, Moinuddin, Ali A, Ali R. Preferential recognition of peroxynitrite modified human DNA by circulating autoantibodies in cancer patients. Cell Immunol. 2009;254:117-23.

45. Dwivedy I, Devanesan P, Gemonesi P, Rogan E, Cavalieri E. Synthesis and characterization of estrogen 2,3 and 3,4 quinones. Comparison of DNA adducts formed by quinones vs. horse reddish peroxidase activated catechol estrogens. Chem Res Toxicol. 1992;5:828-33.

46. Yager JD, Liehr JG. Molecular mechanisms of estrogen carcinogenesis. Annu Rev Pharmacol Toxicol. 1996;36:203-32.

47. Liehr JG, Ricci MJ. 4-Hydroxylation of estrogens as marker of human mammary tumor. Proc Natl Acad Sci USA. 1996;93: 3294-6.

48. Liehr JG, Ricci MJ, Jefcoate CR, Hannigan EV, Hokanson JA, Zhu BT. 4-Hydroxylation of estradiol by human uterine myometrium and myoma microsomes: implications for the mechanism of uterine tumorigenesis. Proc Natl Acad Sci USA. 1995;92:9220-4.

49. Khan WA, Alam K, Moinuddin. Catechol-estrogen modified DNA: a better antigen for cancer autoantibody. Arch Biochem Biophys. 2007;465:293-300.

50. Beckman JS. Oxidative damage and tyrosine nitration by peroxynitrite. Chem Res Toxicol. 1996;9:836-44.

51. Eiserich JP, Hristova M, Goss CE, Jones AD, Freeman BA, Halliwell B, Vander Vliet A. Formation of nitric oxide derived inflammatory oxidants by myeloperoxidase in neutrophils. Nature. 1998;391:393-7.

52. Kaur H, Halliwell B. Evidence for nitric oxide mediated oxidative damage in chronic inflammation, nitrotyrosine in serum and synovial fluid from rheumatoid patients. FEBS Lett. 1994;350:9-12. 
53. Khan F, Siddiqui AA. Prevalence of anti-3-nitrotyrosine antibodies in the joint synovial fluid of patients with rheumatoid arthritis, osteoarthritis and systemic lupus erythematosus. Clin Chim Acta. 2006;370:100-7.

54. Sampson JB, Ye Y, Rosen H, Beckman JS. Myeloperoxidase and horseradish peroxidase catalyze tyrosine nitration in proteins from nitric oxide and hydrogen peroxide. Arch Biochem Biophys. 1998;356:207-13.

55. Watanabe N, Miura S, Zeki S, Ishii H. Hepatocellular oxidative DNA injury induced by macrophage-derived nitric oxide. Free Radic Biol Med. 2001;30:1019-28.

56. Marletta MA. Mammalian synthesis of nitrite, nitrate, nitric oxide and N-nitrosating agents. Chem Res Toxicol. 1988;1: 249-57.

57. Miles AM, Gibson M, Krishna M, Cook JC, Pacelli R, Wink DA, Grisham MB. Effects of superoxide on nitric oxide dependent N-nitrosation reactions. Free Radic Res. 1995;233: 379-90.

58. Liu RH, Baldwin B, Tennant BC, Hotchkiss JH. Elevated formation of nitrate and $\mathrm{N}$-nitrosodimethylamine is wood chucks (Marmota monax) associated with chronic woodchuck hepatitis virus infection. Cancer Res. 1991;51:3925-9.

59. Liu RH, Jacob JR, Tennant BD, Hotchkiss JH. Nitrite and nitrosoamine synthesis by hepatocytes isolated from normal woodchucks, (Marmota Monax) and woodchucks chronically infected with woodchuck hepatitis virus. Cancer Res. 1992;52: 3925-9.

60. Merchant K, Chen H, Gonzalez TC, Keefer LK, Shaw BR. Deamination of single stranded DNA cytosine residues in aerobic nitric oxide solution at micromolar total NO exposures. Chem Res Toxicol. 1996;9:891-6.

61. Wink DA, Look JA, Kim S, Vodovotz Y, Pacelli R, Krishna MC, Russo A, Mitchel JB, Jourdheuil D, Miles AM, Grisham MB. Superoxide modulates the oxidation and nitrosation of thiols by nitric oxide derived reactive intermediates. J Biol Chem. 1997;272:11147-51.

62. Inous S, Kawanishi S. Oxidative DNA damage induced by simultaneous generation of nitric oxide and superoxide. FEBS Lett. 1995;371:86-8.

63. Billar TR. The delicate balance of nitric oxide and superoxide in liver pathology. Gastroenterology. 1995;108:603-5.

64. Ioannidis I, de Groot H. Cytotoxicity of nitric oxide in Fu5 hepatoma cells: evidence for co-operative action with hydrogen peroxide. Biochem J. 1993;296:341-5.

65. Wink DA, Ford PC. Nitric oxide reactions important to biological systems, a survey of some kinetics investigations. Methods. 1995;7:14-20.

66. Darley-Usmar V, Wiseman H, Halliwell B. Nitric oxide and oxygen radicals: a question of balance. FEBS Lett. 1995;369: 131-5.

67. Lim S, Hung AC, Porter AG. Focused PCR screen reveals p53 dependence of nitric oxide-induced apoptosis and up-regulation of maspin and plasminogen activator inhibitor-1 in tumor cells. Mol Cancer Res. 2009;7:55-66.

68. Forrester K, Ambs S, Upold SE, Kapust RB, Spillare EA, Weinberg WC, E Felly-Bosco, Wang XW, Geller DA, Tzeng E, Billar T, Harris CC. Nitric oxide induced p53 accumulation and regulation of inducible nitric oxide synthase expression by wild type p53. Proc Natl Acad Sci USA. 1993;93:2442-7.

69. Kurose I, Miura S, Fukumura D, Yonei Y, Saito H, Tada S, Suematsu M, Tsuchiya M. Nitric oxide mediates kupffer cell-induced reduction of mitochondrial energization in hepatoma cells: a comparison with oxidative burst. Cancer Res. 1993;53:2676-81.

70. Xio L, Eneroth PHE, Qureshi GA. Nitric oxide synthase pathway may mediate human natural killer cell cytotoxicity. Scand J Immunol. 1995;42:505-11.
71. Roit I, Brostoff J, Male DK, editors. Immunology. 3rd ed. St. Louis: Mosby. 1993;16 pp.

72. Gorbunov NV, Osipov AN, Day BW, Zayas RB, Kagan VE, Elsayed NM. Reduction of ferryl myoglobulin and ferryl hemoglobulin by nitric oxide: a protective mechanism against ferryl hemoprotein induced oxidations. Biochemistry. 1995;34: 6689-99.

73. Gardner TE, Naoma H, Daly JM. Peritoneal and splenic macrophage function in tumor bearing host. J Surg Res. 1995;59: 305-10.

74. Lejeune P, Lagade CP, Orier N, Pinard D, Oshima H, Jeannin JF. Nitric oxide involvement in tumour induced immunosuppression. J Immunol. 1994;152:5077-83.

75. Tsurumi Y, Murohara T, Krasinski K, Chen D, Witzenbchler B, Kearney M, Couffinhal T, Isner JM. Reciprocal relation VEGF and NO in the regulation of endothelial integrity. Nat Med. 1997;3:879-86.

76. Luperchio S, Tamir S, Tannenbaum SR. Nitric oxide induced oxidative stress, glutathione metabolism in rodent and human cells. J Exp Med. 1996;181:1333-43.

77. Petit JF, Nicaise M, Lopoivre M, Guissani A, Lemaire G. Protection by glutathione against the antiproliferative effects of nitric oxide: dependence on kinetics of nitric oxide release. Biochem Pharmacol. 1996;52:205-12.

78. Kong L, Dunn GD, Keefer LK, Korthuis RJ. Nitric oxide reduces tumor cell adhesion to isolated rat post capillary vennules. Clin Exp Metastasis. 1996;14:335-43.

79. Murata J, Ricciardi-Castagnoli P, Dessous LE, Mange P, Martin F, Juitlert-Jeanneret L. Microglial cells induce cytotoxic effects towards colon carcinoma cells: measurement of tumor cytotoxicity with a gamma glutamyl transpeptidase assay. Int $\mathrm{J}$ Cancer. 1997;70:169-74.

80. Hiranao S. In vitro and in vivo cytotoxic effects of nitric oxide on metastatic cells. Cancer Lett. 1997;115:56-62.

81. Claney RM, Abramson SB. Nitric oxide: a novel mediator of inflammation. Soc Exp Biol Med. 1995;210:93-101.

82. Kubes PM, Suzuki M, Granger DN. Nitric oxide: an endogenous modulator of leucocyte adhesion. Proc Natl Acad Sci USA. 1991;88:4651-5.

83. Roissaint R, Falke KJ, Lobez F, Slama K, Pison U, Zapol WM. Inhaled nitric oxide for the adult respiratory distress syndrome. N Eng J Med. 1993;328:339-405.

84. Lafer AM. Cytoprotective action of nitric oxide donors in ischemia reperfusion injury. In: Moncada S, Marletta MA, Higgs EA, editors. The biology of nitric oxide. London: Portland Press; 1992. p. 55-8.

85. Nguyen J, Brunson D, Crespi CL, Penman BW, Wishnok JS, Tannenbaum SR. DNA damage and mutation in human cells exposed to nitric oxide. Proc Natl Acad Sci USA. 1992;89: 3030-4.

86. Routledge MN, Wink DA, Keefer LK, Dipple A. Mutations induced by saturated aqueous nitric oxide in psp189 sup. F gene in human Ad293 and E. coli MBM 7070 cells. Carcinogenesis. 1993:14:1251-4.

87. Oshima H, Yoshie Y, Auriol S, Gilbert I. Anti-oxidant and prooxidant actions of flavonoids: effect on DNA damage induced by nitric oxide, peroxynitrite and nitroxyl anion. Free Radic Biol Med. 1998;25:1057-65.

88. Carreira BP, Morte MI, Inácio A, Costa G, Rosmaninho-Salgado J, Agasse F, Carmo A, Couceiro P, Brundin P, Ambrósio AF, Carvalho CM, Araújo IM. Nitric oxide stimulates the proliferation of neural stem cells bypassing the epidermal growth factor receptor. Stem Cells. 2010;28:1219-30.

89. Cerutti P, Gosh R, Oya Y, Amstad P. The role of cellular defense in oxidant carcinogenesis. Environ Health Prospect. 1994;102:123-9. 
90. Ames BN. Endogenous oxidative DNA damage, ageing and cancer. Free Radic Res Commun. 1989;7:121-8.

91. Abdi S, Ali A. Role of ROS modified human DNA in pathogenesis and etiology of cancer. Cancer Lett. 1999;142:1-9.

92. Burney S, Tamir S, Gal A, Tannenbaum SR. A mechanistic analysis of nitric oxide induced cellular toxicity. Nitric Oxide Biol Med. 1997;1:130-44.

93. Stopper H, Moller M, Bommell HM, Schmid HHHW. Cytotoxic versus genotoxic effects of nitric oxide (NO). Toxicol Lett. 1999;106:59-67.

94. Beckman JS. Peroxynitrite versus hydroxy radical: the role of nitric oxide in superoxide dependant cerebral injury. Ann NY Acad Sci. 1994;738:69-74.

95. Marla SS, Lee J, Groves JT. Peroxynitrite rapidly permeates phospholipid bilayers. Proc Natl Acad Sci USA. 1997;94: 14243-8.

96. Angard E. Nitric oxide: mediator, murderer and medicine. Lancet. 1994;343:1199-206.

97. Thomsen LL, Lawton FG, Knowles RG, Beesley JE, RiverosMoreno V, Moncada S. Nitric oxide synthase activity in human gynecological cancer. Cancer Res. 1994;54:1352-4.

98. Thomsen LL, Miles DW, Happerfield L, Bobrow LG, Knowles RG, Moncada S. Nitric oxide synthase activity in human breast cancer. Br J Cancer. 1995;72:41-4.

99. Iwata S, Nakagawa K, Hironobou H, Oka Y, Kumon S, Sakaki S. Endothelial nitric oxide synthase expression in tumor vasculature is correlated with malignancy in human supratentorial astrocytic tumors. Neurosurgery. 1999;45:1-4.

100. Oshima H, Bartch H. Chronic infection and inflammatory process as cancer risk factors: possible role of nitric oxide in carcinogenesis. Mutat Res. 1994;305:253-64.

101. Wiseman H, Halliwell B. Damage to DNA by the reactive oxygen and nitrogen species: role in inflammatory disease and progression to cancer. J Biochem. 1996;313:17-29.

102. Wink DA, Hanbaurer I, Grisham MB, Laval F, Nims RW, Laval J, Cook JC, Pacelli R, Liegmann J, Krishna MC, Ford MC, Mitchell JB. The chemical biology of NO: insights into regulation, protective and toxic mechanisms of nitric oxide. Curr Top Cell Regul. 1996;34:159-87.

103. Correa P, Haenszel W, Cuello C, Tannenbaum S, Archer M. A model for gastric cancer epidemiology. Lancet. 1975;2:58-60.

104. Lintas CL, Clark A, Fox J, Tannenbaum SR, Newberne PM. In vivo stability of nitrite and nitrosamine formation in the dog stomach: effect of nitrite and amine concentration and of ascorbic acid. Carcinogenesis. 1982;3:161-5.

105. Maeda H, Noguchi Y, Sato K, Akaike T. Enhanced vasculature permeability in solid tumors is mediated by nitric oxide and inhibited by both nitric oxide scavenger and nitric oxide synthase inhibitor. Jpn J Cancer Res. 1994;85:331-4.

106. Noguchi Y, Fujii S, Beppu T, Ogawa M, Maeda H. Excessive production of nitric oxide in rat solid tumours and its implications in rapid tumour growth. Cancer. 1996;77:1598-604.

107. Estevez AG, Radi R, Barbeito L, Shin JT, Thompson TA, Beckman JS. Peroxynitrite induced cytotoxicity in PC12 cells: evidence for an apoptic mechanism differentially modulated by neurotrophic factors. J Neurochem. 1995;65:1543-50.

108. Lin KY, Xue JT, Nomen M, Spur B, Wong PYK. Peroxynitrite induced apoptosis in HL 60 cells. J Biol Chem. 1995;270: 16487-90.

109. Bonfoco E, Krainc D, Ankarcrona M, Nicotera P, Lipton SA. Apoptosis and necrosis: two distinct events induced respectively by mild and intense insults with $N$-methyl-D-aspartate or nitric oxide/superoxide in cortical cell cultures. Proc Natl Acad Sci USA. 1995;92:7162-6.

110. Michael PM. Nitric oxide and cell death. Biochim Biophys Acta. 1999;1411:401-14.
111. Lepoivre M, Flaman JM, Bobe P, Lemaire G, Henry Y. Quenching of the tyrosyl free radical of ribonucleotide reductase by nitric oxide. Relationship to cytostasis induced in tumour cells by cytotoxic macrophages. J Biol Chem. 1994;269: 21891-7.

112. Lautier D, Logueux J, Thibodeau J, Menard L, Poirier GG. Molecular and biochemical features of poly(ADP) ribose metabolism. Mol Cell Biochem. 1993;122:171-93.

113. Zhang J, Dawson VL, Dawson TM, Snyder SH. Nitric oxide activation of poly(ADP-ribose) synthase in neurotoxicity. Science. 1994;263:687-9.

114. Szabo C, Zingreli B, Connor MO, Salzman AL. DNA strand breakage, activation of poly(ADP-ribose) synthase, and cellular energy depletion are involved in cytotoxicity in macrophages and smooth muscle cells exposed to peroxynitrite. Proc Natl Acad Sci USA. 1996;93:1753-8.

115. Wink DA, Nims RW, Darbyshire JF, Christodoulou D, Hanbauer I, Cox GW, Laval F, Laval J, Cook JA, Krishna MC, De Graff W, Mitchell JB. Reaction kinetics for nitrosation of cysteine and glutathione in aerobic nitric oxide solutions at neutral $\mathrm{pH}$. Insights into the fate and physiological effects of intermediates generated in $\mathrm{NO} / \mathrm{O}_{2}$ reaction. Chem Res Toxicol. 1994; 7:519-25.

116. Ling-Ling C, Nakamura T, Nakatsu Y, Sakumi K, Hayakawa $\mathrm{H}$. Specific amino acid sequences required for $\mathrm{O}^{6}$ methyl guanine-DNA methyl transferase activity: analysis of these residues at or near the methyl residues site. Carcinogenesis. 1992;83:837-43.

117. Zak P, Kliebl K, Laval F. Repair of $\mathrm{O}^{6}$ methyl guanine and $\mathrm{O}^{4}$ methyl thymine by human and rat $\mathrm{O}^{6}$ methyl guanine-DNAmethyl transferase. J Biochem. 1994;269:730-3.

118. Wink DA, Laval J. The Fpg protein, a DNA repair enzyme is inhibited by the biomediator nitric oxide, in vitro and in vivo. Carcinogenesis. 1994;15:2125-9.

119. Wolosker H, Panizzutti R, Engeklender S. Inhibition of creatine kinase by $S$-nitrosoglutathione. FEBS Lett. 1996;392:274-6.

120. Schweizer M, Richter C. Nitric oxide potently and reversibly deenergizes mitochondria at low oxygen tensions. Biochem Biophys Res Commun. 1994;204:169-75.

121. Konorev EA, Kalyanaraman B. Rapid and irreversible inhibition of creatine kinase by peroxynitrile. FEBS Lett. 1998;427:171-4.

122. Brown GC, Cooper CE. Nanomolar concentrations of nitric oxide reversibly inhibit synaptosomal respiration by competing with oxygen at cytochrome oxidase. FEBS Lett. 1994;356: 295-8.

123. Poderoso JJ, Carreras MC, Lisdero C, Riobo N, Schopfer F, Boveris A. Nitric oxide inhibits electron transfer and increase superoxide radical production in rat heart mitochondria and submitochondrial particles. Arch Biochem Biophys. 1996;328: 85-92.

124. MacMillan LA, Crog JP, Crow JD, Kerby JS, Beckman JA. Nitration and inactivation of manganese superoxide dismutase in chronic rejection of human renal allografts. Proc Natl Acad Sci USA. 1996;95:11853-8.

125. Sazabo C, Salzman AL. Endogenous peroxynitrite is involved in the inhibition of mitochondrial respiration in immuno-stimulated J774.2 macrophages. Biochem Biophys Res Commun. 1995;209:739-43.

126. Hausladen A, Fridovich I. Superoxide and peroxynitrite inactivate aconitases, nitric oxide does not. J Biol Chem. 1994;269: 29405-8.

127. Brown GC. Nitric oxide regulates mitochondrial respiration and cell functions by inhibiting cytochrome oxidase. FEBS Lett. 1995;369:136-9.

128. Scarlet JL, Packer MA, Porteous CM, Murphy MP. Alteration to glutathione and nicotinamide nucleotides during the 
mitochondrial permeability transition induced by peroxynitrite. Biochem Pharmacol. 1996;52:1047-55.

129. Schweizer M, Richter C. Peroxynitrite stimulates the pyridine nucleotide linked $\mathrm{Ca}$ release from intact rat liver mitochondria. Biochemistry. 1996;35:4524-8.

130. Nicotera P, Orrenius S. $\mathrm{Ca}^{2+}$ and cell death. Ann NY Acad Sci. 1992;648:17-27.

131. Gunter TE, Gunter KK, Sheu SS, Gavin CE. Mitochondrial Ca transport: physiology and pathological relevance. Am J Physiol. 1994;267:C313-39.

132. Richter C, Godvadge V, Schlapbach R, Schhweizer M, Schlegel J. Nitric oxide kills hepatocytes by mobilizing mitochondrial calcium. Biochem Biophys Res Commun. 1994;205:1143-50.

133. Zoratti M, Sazabo I. The mitochondrial permeability transition. Biochim Biophys Acta. 1995;1241:139-76.

134. Cassina A, Radi R. Differential inhibitory action of nitric oxide and peroxynitrite on mitochondrial electron transport. Arch Biochem Biophys. 1996;328:309-16.

135. Radi R, Beckman JS, Bush KM, Freeman BA. Peroxynitrite induced membrane lipid peroxidation: the cytotoxic potential of superoxide and nitric oxide. Arch Biochem Biophys. 1991;288: 481-7.

136. Vander VA, Smith D, O'Neill CA, Kaur H, Usmar VD, Halliwell CEB. Interactions of peroxynitrite with human plasma and its constituents: oxidative damage and antioxidant depletion. Biochem J. 1994;303:295-301.

137. Burney S, Tamir S, Gal A, Tannenbaum SR. A mechanistic analysis of nitric oxide induced cellular toxicity. Nitric Oxide Biol Chem. 1997;1:130-44.

138. Radi R, Rodriguez M, Castro L, Telleri R. Inhibition of mitochondrial electron transport by peroxynitrite. Arch Biochem Biophys. 1994;308:89-95.
139. Packer MA, Murphy MP. Peroxynitrite causes Ca efflux from mitochondria which is prevented by cyclosporin A. FEBS Lett. 1994;345:237-40.

140. Richter C, Goavadze V, Laffranchi R, Schlapbach R, Schweizer M, Suter M, Walter P, Yaffee M. Oxidants in mitochondria: from physiology to diseases. Biochim Biophys Acta. 1995;1271: 67-74.

141. Gordge MP. How cytotoxic is nitric oxide. Exp Nephrol. 1998;6:12-6.

142. Rodes D, Klug A. Zinc fingers. Sci Am. 1993;268:55-6.

143. Marcello NM, John LW. Nitric oxide. V. Therapeutic potential of nitric oxide donors and inhibitors. Am J Physiol. 1999;276: G1313-6.

144. Nathan C, Xie Q. Regulation of biosynthesis of nitric oxide. J Biol Chem. 1994;269:13725-8.

145. Moncada S, Palmer RMJ, Higgs EA. Nitric oxide physiology pathophysiology and pharmacology. Pharmacol Rev. 1991;43: 109-42.

146. Bredt DS, Snyder SH. Nitric oxide a novel neuronal messenger. Neuron. 1992;8:3-11.

147. Sikora AG, Gelbard A, Davies MA, Sano D, Ekmekcioglu S, Kwon J, Hailemichael Y, Jayaraman P, Myers JN, Grimm EA, Overwijk WW. Targeted inhibition of inducible nitric oxide synthase inhibits growth of human melanoma in vivo and synergizes with chemotherapy. Clin Cancer Res. 2010;16:1834-44.

148. Hirst DG, Robson T. Nitric oxide physiology and pathology. Methods Mol Biol. 2011;704:1-13. 